\title{
Porous structure and adsorptive properties of hide waste activated carbons prepared via potassium silicate activation
}

\author{
Jiaojiao Kong ${ }^{\mathrm{a}}$, Qinyan Yue ${ }^{\mathrm{a}_{*},}$, Baoyu Gao ${ }^{\mathrm{a}}$, Qian $\mathrm{Li}^{\mathrm{a}}$, Yan Wang ${ }^{\mathrm{a}}$, Huu Hao Ngo ${ }^{\mathrm{b}}$, \\ Wenshan Guo ${ }^{\mathrm{b}}$ \\ a Shandong Provincial Key Laboratory of Water Pollution Control and Resource Reuse, School of \\ Environmental Science and Engineering, Shandong University, Jinan 250100, China \\ b Centre for Technology in Water and Wastewater, School of Civil and Environmental Engineering, University \\ of Technology, Broadway, Sydney, NSW 2007, Australia \\ * Corresponding author, E-mail address: qyyue58@aliyun.com (Q. Yue); Tel.: +86 53188365258 ; \\ Fax: +8653188364513 .
}

\begin{abstract}
A novel activating agent, potassium silicate, was employed in the preparation of hide waste activated carbon. Effects of different activation temperatures and impregnation ratios on porous activated carbon evolution were evaluated by nitrogen adsorption/desorption. The BET specific surface area and pore volume of prepared activated carbon could attain $2046.12 \mathrm{~m}^{2} / \mathrm{g}$ and $1.068 \mathrm{~cm}^{3} / \mathrm{g}$, when the process of preparation carried out at the best conditions (activation temperature of $700^{\circ} \mathrm{C}$ and the impregnation ratio of $2: 1$ ). Methylene blue (MB) was selected as the adsorbate to evaluate its adsorption property. Adsorption results can be fitted well by the Langmuir isotherm, indicating the maximum monolayer adsorption capacity of MB reached to $769.23 \mathrm{mg} / \mathrm{g}$.
\end{abstract}

Keywords: Activated carbon; Potassium silicate; Hide waste; Methylene blue 


\section{Introduction}

Activated carbon, the most common and effective adsorbent, has large specific surface area, complex aperture structure and variety of functional groups, which can be prepared by any carbonaceous materials. Today, waste materials such as macadamia nut endocarp [1], lotus stalk [2], waste tires [3] etc. are transformed into activated carbons, which has become one of the research focuses. When raw hide and skin convert into leather, solid and liquid wastes would produce. The solid waste such as hide waste (HW) had keratin ingredient which was often discarded due to the low economic benefits, thus the reasonable application of this solid waste should be studied further. Nevertheless, according to the literature, there is little information about the preparation of activated carbon from HW.

There are two main activation methods in the preparation of activated carbon, namely physical and chemical methods. As to chemical method, $\mathrm{KOH}, \mathrm{NaOH}, \mathrm{H}_{3} \mathrm{PO}_{4}$ and $\mathrm{ZnCl}_{2}$ were often used as the activating agents [4]. The carbon produced by $\mathrm{KOH}$ or $\mathrm{NaOH}$ generally has microporous structure, whereas $\mathrm{KOH}$ or $\mathrm{NaOH}$ can corrode apparatus whose life would be shortened and thus limit the development and application of this activating agent. Actually, silicone material is widely used as flame retardants in the field of extinguishing as a result of hindering the combustion of materials from originating [5]. However, to our knowledge, there are no papers using potassium silicate $\left(\mathrm{K}_{2} \mathrm{SiO}_{3}\right)$ as the activating agent for preparing activated carbon. The purpose of this study was to prepare hide waste activated carbon (HWAC), using $\mathrm{K}_{2} \mathrm{SiO}_{3}$ as the activating agents to evaluate the pore structure and adsorption properties. 


\section{Materials and methods}

\subsection{Preparation of activated carbons}

HW was provided by a tanning industry from Shandong province in China. The raw material was first soaked with ethanol for $48 \mathrm{~h}$ to remove some fat, then washed and dried at $60{ }^{\circ} \mathrm{C}$. The dried materials were cut into particles of $0.5 \mathrm{~cm} \times 0.5 \mathrm{~cm}$, then dipped with a certain concentration of $\mathrm{K}_{2} \mathrm{SiO}_{3}$ solution to a varying impregnation ratio of 1:1-3:1 ( $\mathrm{R}, \mathrm{g}$ $\mathrm{K}_{2} \mathrm{SiO}_{3} / \mathrm{g} \mathrm{HW}$ ). After impregnation for $12 \mathrm{~h}$, the mixtures were heated at $105{ }^{\circ} \mathrm{C}$ for $30 \mathrm{~min}$ to evaporate some of water. Samples were heated to the desired temperatures $(400,500,600$, 700 , and $800^{\circ} \mathrm{C}$ ) in a tube furnace, and maintained for $1 \mathrm{~h}$ under a stable nitrogen flow $(100 \mathrm{~mL} / \mathrm{min})$. The products were washed with hot water and distil water to ensure the $\mathrm{pH}$ of washing liquid attained neutral, and then dried at $105{ }^{\circ} \mathrm{C}$ for $12 \mathrm{~h}$. Finally, the desired carbons were sieved to a particle size of $0.076-0.15 \mathrm{~nm}$, and stored in a desiccator for the next study.

\subsection{Characterization of $\mathrm{HW}-\mathrm{K}_{2} \mathrm{SiO}_{3}$ and $\mathrm{HWAC}$}

The thermogravimetric analysis (TGA) and derivative thermogravimetric (DTG) curves of $\mathrm{HW}$ after $\mathrm{K}_{2} \mathrm{SiO}_{3}$ impregnated were acquired by an SDT-simultaneous TGA-DTA model, which were performed in pure $\mathrm{N}_{2}$ atmosphere $(100 \mathrm{~mL} / \mathrm{min})$. The mixture was heated at the heating rate of $10^{\circ} \mathrm{C}$ from room temperature to $700{ }^{\circ} \mathrm{C}$, and held this temperature for $1 \mathrm{~h}$. The BET specific surface area $\left(S_{\mathrm{BET}}\right)$ and pore size distribution of HWACs were characterized using a surface area analyzer (JW-BK122W, China) by $\mathrm{N}_{2}$ adsorptiondesorption isotherm at $77 \mathrm{~K}$. The surface morphology of activated carbon was determined by scanning electron microscopy (SEM) (HitachiS-520, Japan). 


\subsection{Equilibrium adsorption experiment}

Activated carbon under the conditions of the activated temperature of $700{ }^{\circ} \mathrm{C}$ and the impregnation ratio of 2:1 with the highest $S_{\mathrm{BET}}(\mathrm{AC})$ was selected to perform the adsorption experiments. Batch experiments were conducted in a series of $150-\mathrm{mL}$ conical flasks containing $50 \mathrm{~mL} \mathrm{MB}$ and $0.05 \mathrm{~g}$ adsorbents with different initial concentrations ranging from 75 to $900 \mathrm{mg} / \mathrm{L}$. The flakes were placed in a thermostatic shaker (SHA-B, Shanghai, China) and shaken at $25{ }^{\circ} \mathrm{C}$ with a speed of $160 \mathrm{rpm}$ for $24 \mathrm{~h}$ to ensure the equilibrium. Finally, the concentrations of MB solution after filtrating were determined by a UV-vis spectrophotometer (UV-754, Shanghai) at $\lambda_{\max }=665 \mathrm{~nm}$. Blank experiments without adsorbents were also performed as described above. The adsorption isotherm experiments were carried out in duplicate and the mean value was reported. The adsorption capacity, $q_{\mathrm{e}}(\mathrm{mg} / \mathrm{g})$, could be calculated by the equation:

$$
q_{e}=\frac{\left(C_{0}-C_{e}\right) V}{W}
$$

where $C_{0}$ and $C_{\mathrm{e}}(\mathrm{mg} / \mathrm{L})$ are the initial and equilibrium concentrations of MB solutions. $V(\mathrm{~L})$ is the solution volume of MB solutions. $W(\mathrm{~g})$ is the mass of activated carbon.

\subsection{Equilibrium modeling}

The equilibrium data of MB adsorption were modeled using Langmuir [6] and Freundlich [7] equations as follows:

$$
\begin{aligned}
& \frac{C_{e}}{q_{e}}=\frac{1}{q_{m} K_{L}}+\frac{C_{e}}{q_{m}} \\
& \operatorname{Inq}_{e}=\operatorname{In} K_{F}+\frac{1}{n} \operatorname{In} C_{e}
\end{aligned}
$$

where $q_{\mathrm{m}}$ and $q_{\mathrm{e}}(\mathrm{mg} / \mathrm{g})$ are the maximum and the equilibrium adsorption capacities, respectively. $K_{\mathrm{L}}(\mathrm{L} / \mathrm{mg})$ is the Langmuir constant related to the free energy of 
adsorption. $K_{\mathrm{F}}(\mathrm{mg} / \mathrm{g})(\mathrm{L} / \mathrm{mg})^{1 / n}$ and $n$ are the Freundlich constants associated with adsorption intensity.

\section{Results and discussion}

\subsection{Characterization of $\mathrm{HW}-\mathrm{K}_{2} \mathrm{SiO}_{3}$ and $\mathrm{HWAC}$}

\subsubsection{Thermogravimetric analysis of $\mathrm{HW}-\mathrm{K}_{2} \mathrm{SiO}_{3}$}

The TGA and DTG curves of $\mathrm{HW}-\mathrm{K}_{2} \mathrm{SiO}_{3}$ are shown in Fig. 1. TGA profile shows that the process of weight loss contained three sections. The weight loss in the first 20 min could be due to the water evaporation and the degeneration of keratin, reflected in the DTG curve two small peaks. The second stage occurred between $20 \mathrm{~min}$ and $45 \mathrm{~min}$, which attributed to the volatile of organic matter and moisture. The peaks at the temperatures of $287^{\circ} \mathrm{C}$ and $450{ }^{\circ} \mathrm{C}$ in the DTG curve were corresponded with the thermal decomposition of denatured proteins under the catalysis of silicate. After $40 \mathrm{~min}$, the weight loss decreased slightly, illustrating that the catalytic action of $\mathrm{K}_{2} \mathrm{SiO}_{3}$ completed.

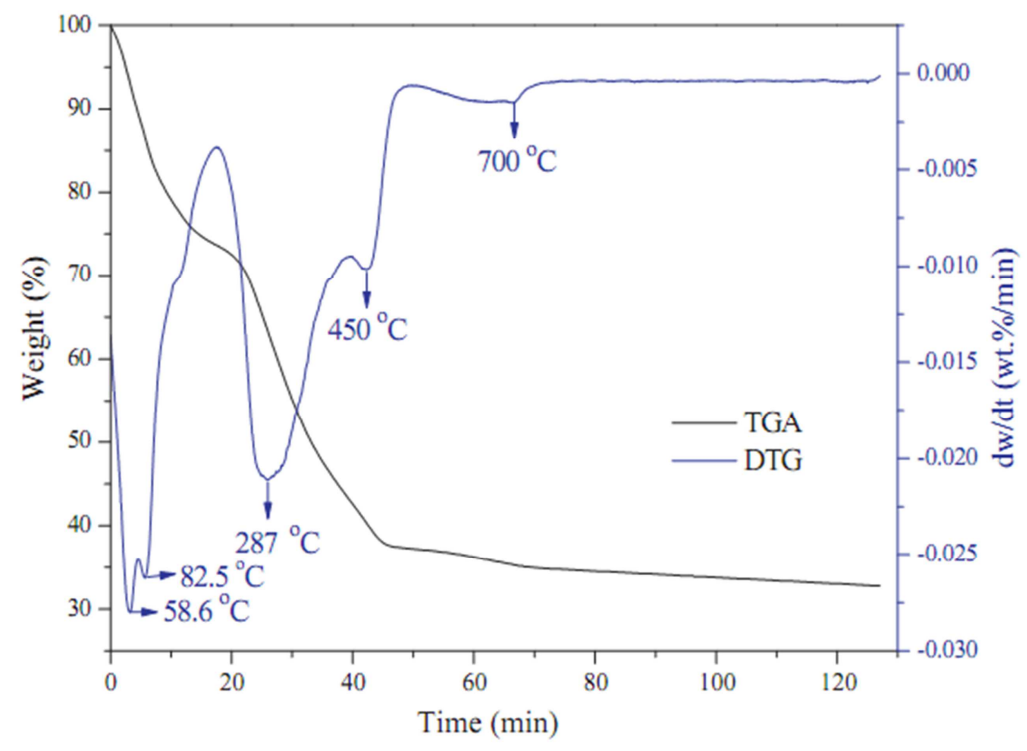

Fig. 1. TGA and DTG curves for the pyrolysis of $\mathrm{HW}-\mathrm{K}_{2} \mathrm{SiO}_{3}$. 


\subsubsection{Nitrogen adsorption behavior and porosity development}

The $\mathrm{N}_{2}$ adsorption/desorption isotherms and pore size distributions of the prepared activated carbons under different conditions are shown in Fig. 2. The $\mathrm{N}_{2}$ adsorption/desorption isotherms reflected different adsorption capacities of nitrogen and hysteresis loops, indicating the appearance of mesopores and presence of majority micropores (AC). The $\mathrm{N}_{2}$ adsorption/desorption curves were mixture of type I and type IV isotherms [8], illustrating the pores of the carbons were micropores and mesopores. Table 1 shows the BET surface areas, pore volumes, and average pore sizes of the prepared activated carbons. It can be concluded that $\mathrm{HW}$ and $\mathrm{K}_{2} \mathrm{SiO}_{3}$ were excellent precursor and activating agent respectively in the preparation of activated carbon. $S_{\mathrm{BET}}$ first increased then decreased with the activated temperature, and it showed the same trend with the impregnation ratio. This may be attributed to high activation energy between carbon atom and $\mathrm{K}_{2} \mathrm{SiO}_{3}$. Consequently, under the conditions of the activated temperature of $700{ }^{\circ} \mathrm{C}$ and the impregnation ratio of $2: 1$, HWAC

had the highest specific surface area $\left(2046 \mathrm{~m}^{2} / \mathrm{g}\right)$ and total pore volume $\left(1.068 \mathrm{~cm}^{3} / \mathrm{g}\right)$. Table 1 also reflects that the high proportion of micropores was beneficial to the high specific surface area, and the majority of pore size was micropores and mesopores. The pore sizes distribution (Fig. 2) reveals that most of the pores ranged around $2 \mathrm{~nm}$, which indicates the activated carbons had micro-mesopores structure, corresponding to the $\mathrm{N}_{2}$ adsorption/desorption results. 

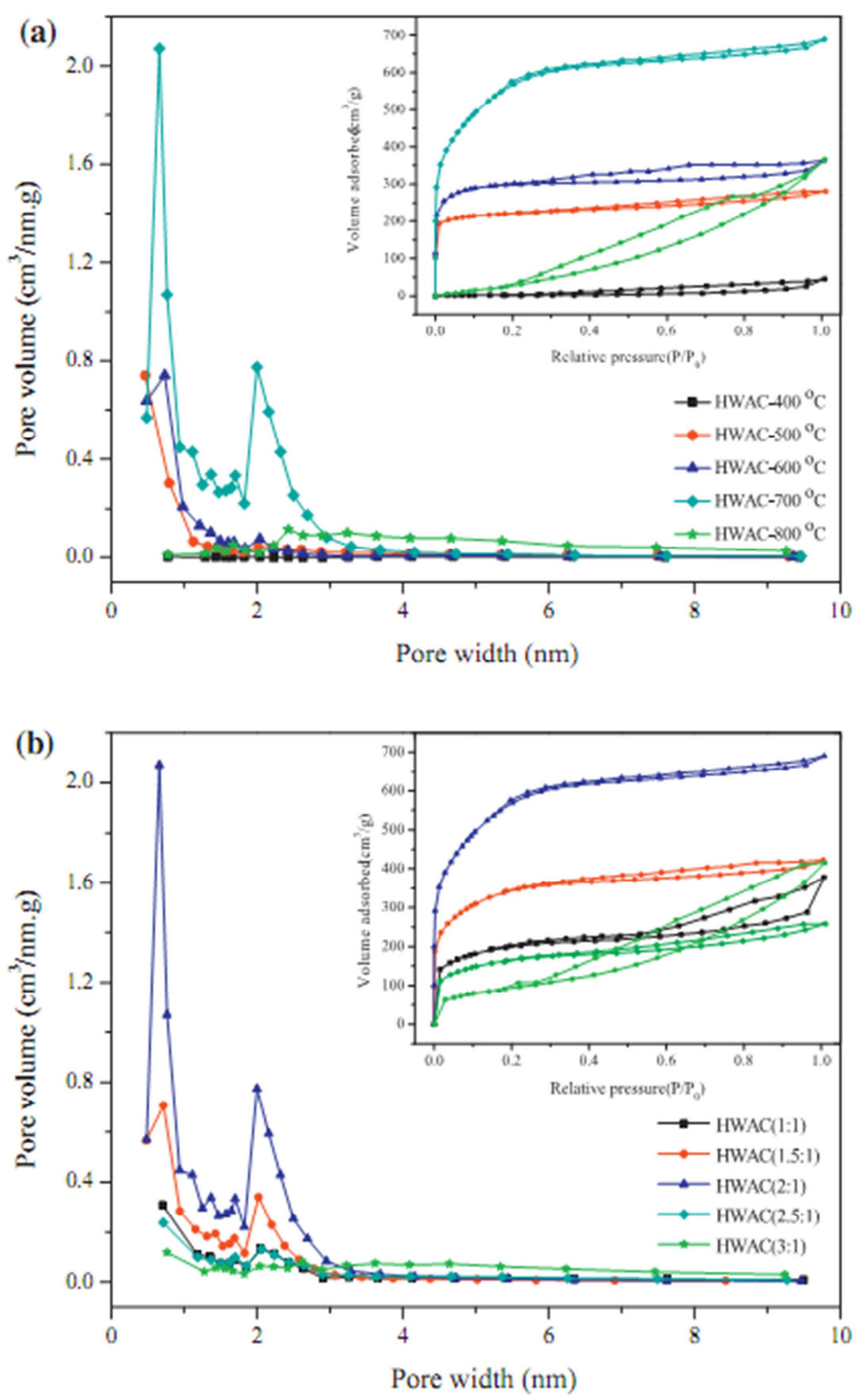

Fig. 2. Effects of (a) activating temperature (preparation condition: $R=2: 1$; activating time $=1 \mathrm{~h}$ ), (b) impregnation ratio (activating temperature $=700^{\circ} \mathrm{C}$; activating time $=1 \mathrm{~h}$ ) on pore size distributions and nitrogen adsorption/desportion isotherms (inset) for HWAC. 


\section{Table 1}

The effect of activation temperature and impregnation ratio on BET surface areas, pore volumes, average pore sizes of activated carbons activated by $\mathrm{K}_{2} \mathrm{SiO}_{3}$.

\begin{tabular}{|c|c|c|c|c|c|c|c|c|}
\hline $\begin{array}{l}\text { Activated } \\
\text { temperatu } \\
\text { re }\left({ }^{\circ} \mathrm{C}\right)\end{array}$ & $R$ & $S_{\mathrm{BET}}{ }^{\mathrm{a}}$ & $\begin{array}{l}S_{\text {mic }}{ }^{\mathrm{b}}\left(\mathrm{m}^{2} /\right. \\
\mathrm{g})\end{array}$ & $\begin{array}{l}S_{\text {mic }} / S_{\text {B }} \\
\text { ET }\end{array}$ & $\begin{array}{l}V_{\text {tot }}{ }^{\mathrm{c}}\left(\mathrm{cm}^{3} /\right. \\
\mathrm{g})\end{array}$ & $\begin{array}{l}V_{\text {mic }}{ }^{\mathrm{d}}\left(\mathrm{cm}^{3} /\right. \\
\mathrm{g})\end{array}$ & $\begin{array}{l}V_{\text {mid }} / V_{\text {tot }}( \\
\%)\end{array}$ & $\begin{array}{l}D_{\mathrm{p}}{ }^{\mathrm{e}}(\mathrm{n} \\
\mathrm{m})\end{array}$ \\
\hline 400 & & 7.93 & 0.318 & 4.01 & 0.071 & 0.0025 & 3.52 & 35.89 \\
\hline 500 & & 791.64 & 697.21 & 88.07 & 0.436 & 0.3371 & 77.32 & 2.20 \\
\hline 600 & $2: 1$ & $\begin{array}{l}1071.8 \\
4\end{array}$ & 1031.29 & 96.23 & 0.563 & 0.4574 & 81.24 & 2.10 \\
\hline 700 & & $\begin{array}{l}2046.1 \\
2\end{array}$ & 1803.20 & 88.13 & 1.068 & 0.8103 & 75.87 & 2.09 \\
\hline 800 & & 175.05 & 11.22 & 6.41 & 0.567 & 0.0307 & 5.41 & 12.95 \\
\hline \multirow{4}{*}{700} & $1: 1$ & 716.69 & 616.38 & 86.00 & 0.585 & 0.2961 & 50.62 & 3.27 \\
\hline & $\begin{array}{l}1.5: \\
1\end{array}$ & $\begin{array}{l}1245.7 \\
0\end{array}$ & 1115.70 & 89.56 & 0.653 & 0.5054 & 77.40 & 2.10 \\
\hline & $\begin{array}{l}2.5: \\
1\end{array}$ & 594.51 & 495.09 & 83.28 & 0.399 & 0.2435 & 61.03 & 2.69 \\
\hline & $3: 1$ & 333.34 & 91.87 & 27.56 & 0.644 & 0.1301 & 20.20 & 7.72 \\
\hline
\end{tabular}

a $S_{\mathrm{BET}}$ : BET specific surface area.

b $S_{\text {mic }}$ : micropore specific surface area.

c $V_{\text {tot }}$ : total pore volume.

d $V_{\text {mic }}$ : micropore volume.

e $D_{\mathrm{p}}$ : the mean pore.

Table 2 shows the element contents of $\mathrm{C}, \mathrm{N}, \mathrm{O}, \mathrm{S}$, and Si of HW and AC. It can be seen that both of $\mathrm{HW}$ and $\mathrm{AC}$ had high content of $\mathrm{C}, \mathrm{N}, \mathrm{O}$, and $\mathrm{S}$ but low Si content. HW contains the protein substance, which explained the higher contents of $\mathrm{N}, \mathrm{S}, \mathrm{O}$ for $\mathrm{HW}$ than AC, but the content of $\mathrm{C}$ increased after activation.

Table 2

Elemental change between HW and AC.

\begin{tabular}{llllll}
\hline & $\mathrm{C}(\%)$ & $\mathrm{N}(\%)$ & $\mathrm{O}(\%)$ & $\mathrm{S}(\%)$ & $\mathrm{Si}(\%)$ \\
\hline $\mathrm{HW}$ & 65.69 & 18.55 & 13.51 & 2.25 & 0 \\
$\mathrm{AC}$ & 87.15 & 6.05 & 6.76 & 0.01 & 0.03 \\
\hline
\end{tabular}


SEM micrographs of AC (Fig. 3) shows that the prepared activated carbon had a smooth surface and highly developed pores. It is indicated that $\mathrm{K}_{2} \mathrm{SiO}_{3}$ favored for the generation of porous structure. $\mathrm{K}^{+}$could transform into elemental potassium, thus massive pores produced [9].
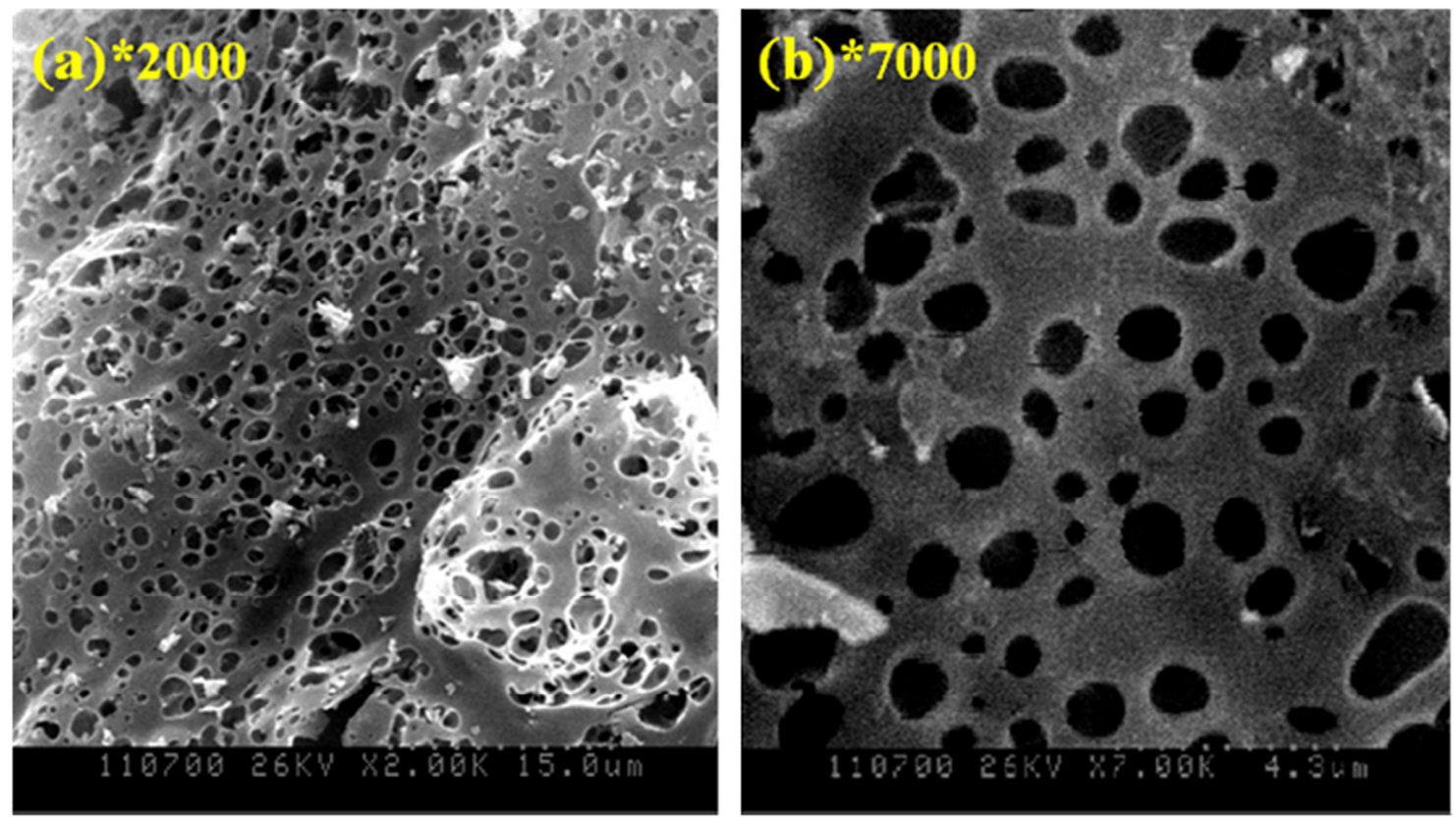

Fig. 3. SEM micrographs of $A C$ at different magnifications $(2000 \times$ and $7000 \times)$.

\subsection{MB adsorption analysis}

The adsorption properties of $\mathrm{AC}$ were evaluated by $\mathrm{MB}$ adsorption to test its adsorption performance. Table 3 shows that Langmuir isotherm was more suitable to describe the adsorption with high correlation coefficient $\left(R^{2}=0.9999\right)$, indicating monolayer coverage of MB molecules and uniform energy. The comparisons of specific surface area and maximum monolayer adsorption capacity of various adsorbents are displayed in Table 4. Compared with the previous study, AC in this work showed high MB adsorption capacity $(769.23 \mathrm{mg} / \mathrm{g}$ ) which was much higher than that of the other adsorbents prepared from other materials and different activating agents. According to the results, $\mathrm{AC}$ as an excellent adsorbent could be 
applied in the removal of dye in wastewater. Hence, $\mathrm{HW}$ and $\mathrm{K}_{2} \mathrm{SiO}_{3}$ were preferable raw material and activating agent in the process of activated carbon preparation.

Table 3

Langmuir and Freundlich isotherm constants for the adsorption of MB onto AC.

\begin{tabular}{llllll}
\hline Langmuir isotherm model & \multicolumn{5}{l}{ Freundich isotherm model } \\
$q_{\mathrm{m}}(\mathrm{mg} / \mathrm{g})$ & $K_{\mathrm{L}}{ }^{\mathrm{a}}(\mathrm{L} / \mathrm{mg})$ & $R^{2}$ & $K_{\mathrm{F}}{ }^{\mathrm{b}}(\mathrm{mg} / \mathrm{g})(\mathrm{L} / \mathrm{mg})^{1 /} n$ & $n^{\mathrm{c}}$ & $R^{2}$ \\
769.23 & 14.44 & 0.9999 & 538.02 & 7.83 & 0.8336 \\
\hline${ }^{\mathrm{a}} K_{\mathrm{L}}:$ Langmuir constant. \\
${ }^{\mathrm{b}} K_{\mathrm{F}}$ : Freundlich constants which relate to the adsorption capacity. \\
${ }^{\mathrm{c}} n$ : Freundlich constants which relate to the adsorption capacity intensity.
\end{tabular}

Table 4

Comparisons of BET specific surface area and MB adsorption capacity of various adsorbents.

\begin{tabular}{lllll}
\hline Precursor & $\begin{array}{l}\text { Activating } \\
\text { agent }\end{array}$ & $S_{\text {BET }}\left(\mathrm{m}^{2} / \mathrm{g}\right)$ & $\begin{array}{l}\text { Adsorption capacity } \\
(\mathrm{mg} / \mathrm{g})\end{array}$ & Reference \\
\hline Rice husks & $\mathrm{KOH}$ & 752 & 362.6 & {$[10]$} \\
\hline Jatropha curcas fruit shell & $\mathrm{NaOH}$ & 1873 & 499.17 & {$[11]$} \\
\hline Rice husks & $\mathrm{K}_{2} \mathrm{CO}_{3}$ & 1165 & 441.52 & {$[10]$} \\
\hline Peach stones & $\mathrm{H}_{3} \mathrm{PO}_{4}$ & 1298 & 412 & {$[12]$} \\
\hline Black liquor lignin & $\mathrm{Steam}_{\text {Cocoa shell }}$ & 310.15 & 92.51 & {$[13]$} \\
Walnut shells & $\mathrm{CO}_{2}$ & 85.09 & 212.77 & {$[14]$} \\
Leather waste & $\mathrm{ZnCl}_{2}$ & 1800 & 315 & {$[15]$} \\
Hide waste & $\mathrm{H}_{4} \mathrm{P}_{2} \mathrm{O}_{7}$ & 638.57 & 303.03 & {$[16]$} \\
\hline
\end{tabular}

\section{Conclusion}

This study highlighted the potential of potassium silicate and hide waste as the efficient activating agent and raw precursor for preparation of activated carbon, respectively. The prepared carbon possessed BET specific surface area as $2046.12 \mathrm{~m}^{2} / \mathrm{g}$ and total pore volume as $1.068 \mathrm{~cm}^{3} / \mathrm{g}$ at the best condition $\left(T=700{ }^{\circ} \mathrm{C}, R=2: 1\right) . \mathrm{K}_{2} \mathrm{SiO}_{3}$ activation enhanced the development of aperture and benefited the production of micro-mesopores carbon. The 
adsorption isotherm results fitted the Langmuir equation with the monolayer adsorption capacity for MB of $769.23 \mathrm{mg} / \mathrm{g}$.

\section{Acknowledgements}

This research was supported by the National Natural Science Foundation of China (21007034), Technology Foresight Program of Shandong province (2012GGE27011), and Foundation for Young Excellent Scientists of Shandong Province (BS2009NY005).

\section{References}

[1] O. Pezoti Junior, A.L. Cazetta, R.C. Gomes, É.O. Barizão, I.P.A.F. Souza, A.C. Martins, T. Asefa, V.C. Almeida, Synthesis of $\mathrm{ZnCl}_{2}$-activated carbon from macadamia nut endocarp (Macadamia integrifolia) by microwave-assisted pyrolysis: optimization using RSM and methylene blue adsorption, J. Anal. Appl. Pyrol. 105 (2014) 166-176.

[2] H. Liu, Q. Gao, P. Dai, J. Zhang, C. Zhang, N. Bao, Preparation and characterization of activated carbon from lotus stalk with guanidine phosphate activation: sorption of Cd(II), J. Anal. Appl. Pyrol. 102 (2013) 7-15.

[3] A. Undri, B. Sacchi, E. Cantisani, N. Toccafondi, L. Rosi, M. Frediani, P. Frediani, Carbon from microwave assisted pyrolysis of waste tires, J. Anal. Appl. Pyrol. 104 (2013) $396-404$.

[4] S. Karagöz, T. Tay, S. Ucar, M. Erdem, Activated carbons from waste biomass by sulfuric acid activation and their use on methylene blue adsorption, Bioresour. Technol. 99 (2008) 6214-6222.

[5] R. Song, L. Chang, B. Li, Flame retardancy and thermal properties of carboxyl-containing polysiloxane derivatives in polycarbonate, J. Appl. Polym. Sci. 131 (2014). 
[6] I. Langmuir, The constitution and fundamental properties of solids and liquids. Part I. Solids, J. Am. Chem. Soc. 38 (1916) 2221-2295.

[7] M. Šćiban, B. Radetić, Ž. Kevrešan, M. Klašnja, Adsorption of heavy metals from electroplating wastewater by wood sawdust, Bioresour. Technol. 98 (2007) 402-409

[8] R. Pierotti, J. Rouquerol, Reporting physisorption data for gas/solid systems with special reference to the determination of surface area and porosity, Pure Appl. Chem. 57 (1985) 603-619.

[9] H. Deng, G. Li, H. Yang, J. Tang, J. Tang, Preparation of activated carbons from cotton stalk by microwave assisted $\mathrm{KOH}$ and $\mathrm{K}_{2} \mathrm{CO}_{3}$ activation, Chem. Eng. J. 163 (2010) 373381.

[10] K.Y. Foo, B.H. Hameed, Utilization of rice husks as a feedstock for preparation of activated carbon by microwave induced $\mathrm{KOH}$ and $\mathrm{K}_{2} \mathrm{CO}_{3}$ activation, Bioresour. Technol. 102 (2011) 9814-9817.

[11] W. Tongpoothorn, M. Sriuttha, P. Homchan, S. Chanthai, C. Ruangviriyachai, Preparation of activated carbon derived from Jatropha curcas fruit shell by simple thermo-chemical activation and characterization of their physico-chemical properties, Chem. Eng. Res. Des. 89 (2011) 335-340.

[12] A.A. Attia, B.S. Girgis, N.A. Fathy, Removal of methylene blue by carbons derived from peach stones by $\mathrm{H}_{3} \mathrm{PO}_{4}$ activation: batch and column studies, Dyes Pigments 76 (2008) 282-289.

[13] K. Fu, Q. Yue, B. Gao, Y. Sun, L. Zhu, Preparation, characterization and application of lignin-based activated carbon from black liquor lignin by steam activation, Chem. Eng. J. 228 (2013) 1074-1082. 
[14] F. Ahmad, W.M.A.W. Daud, M.A. Ahmad, R. Radzi, Cocoa (Theobroma cacao) shellbased activated carbon by $\mathrm{CO}_{2}$ activation in removing of cationic dye from aqueous solution: kinetics and equilibrium studies, Chem. Eng. Res. Des. 90 (2012) 1480-1490.

[15] J. Yang, K. Qiu, Preparation of activated carbons from walnut shells via vacuum chemical activation and their application for methylene blue removal, Chem. Eng. J. 165 (2010) 209-217.

[16] J. Kong, Q. Yue, B. Wang, L. Huang, B. Gao, Y. Wang, Q. Li, Preparation and characterization of activated carbon from leather waste microwave-induced pyrophosphoric acid activation, J. Anal. Appl. Pyrol. 104 (2013) 710-713. 